\title{
EFEKTIFITAS PANAX GINSENG TERHADAP ALOPECIA
}

\author{
Karunia Santi*, Made Merta Jaya \\ Fakultas Kedokteran, Universitas Lampung, J1. Prof. Dr. Ir. Sumantri Brojonegoro No.1, Gedong \\ Meneng, Kec. Rajabasa, Kota Bandar Lampung, Lampung, Indonesia 35145 \\ *karuniasanti@gmail.com (+6282281525798)
}

\begin{abstract}
ABSTRAK
Aspek fungsional rambut pada kepala tidak hanya untuk melindungi dari radiasi matahari dan paparan panas / dingin, tetapi juga untuk berkontribusi pada penampilan dan kepribadian seseorang. Kerontokan rambut progresif memiliki dampak kosmetik dan sosial. Rambut mengalami tiga tahap siklus rambut: fase anagen, catagen, dan telogen. Melalui kehilangan siklus dan pertumbuhan rambut baru, jumlah rambut tetap relatif konstan. Berbagai faktor, seperti hormon, status gizi, dan paparan radiasi, racun lingkungan, dan obat-obatan, dapat memengaruhi pertumbuhan rambut. Androgen adalah faktor terpenting yang menyebabkan alopesia androgenik. Bentuk lain dari kerontokan rambut termasuk kerontokan rambut imunogenik, yaitu alopecia areata. Meskipun sejumlah terapi, seperti finasteride dan minoxidil, adalah obat yang disetujui pencarian terhadap obat obatan alami atau tradisional tetap diperhitungkan salah satunya adalah ginseng. Sejumlah produk - produk sampo dan kondisioner memsukan bagian ginseng, telah menunjukkan pertumbuhan rambut mempromosikan efek dalam sejumlah besar studi praklinis. Penelitian ini merupakan studi literature review.Tujuan dari tinjauan ini adalah melihat potensi ginseng dan metabolitnya pada pencegahan rambut rontok dan mekanisme yang mendasarinya.
\end{abstract}

Kata kunci: alopecia, kerontokan rambut, ginseng

\section{EFFECTIVENESS OF PANAX GINSENG ON ALOPECIA}

\begin{abstract}
The functional aspect of hair on the head is not only to protect from sun radiation and heat I cold exposure, but also to contribute to one's appearance and personality. Progressive hair loss has cosmetic and social effects. Hair experiences three stages of the hair cycle: anagen, catagen, and telogen phases. Through cycle loss and new hair growth, the amount of hair remains relatively constant. Various factors, such as hormones, nutritional status, and radiation exposure, environmental toxins, and medications, can affect hair growth. Androgens are the most important factor causing androgenic alopecia. Other forms of hair loss include immunogenic hair loss, namely alopecia areata. Although a number of therapies, such as finasteride and minoxidil, are drugs that are approved by the search for natural or traditional medicines, one of which is still considered ginseng. A number of shampoo and conditioner products, which have a part of ginseng, have shown hair growth - promoting effects in a large number of preclinical studies. This study used literatur review. The purpose of this review is to look at the potential of ginseng and its metabolites in the prevention of hair loss and the underlying mechanisms.
\end{abstract}

Keywords:alopecia, hair loss, ginseng

\section{PENDAHULUAN}

Rambut memberikan kontribusi daya tarik perlindungan, sensorik, dan seksual dan juga sering digunakan untuk menunjukkan keyakinan pribadi atau posisi sosial. Selama kehidupan pascakelahiran, rambut 
secara siklik mengalami tiga fase pertumbuhan cepat yaitu anagen (2 - 6 tahun), regresi yang dimediasi apoptosis (catagen, 2 - 3 minggu), dan ketenangan relatif (telogen, 2 - 3 bulan)(Kimura-Ueki et al., 2012). Keratinosit matriks rambut pada fase anagen adalah beberapa sel pembagi tercepat dalam tubuh, dengan $60 \%$ di antaranya tersisa dalam fase S(Hirobe, 2014).

Alopesia merupakan suatu keadaan hilang atau tidak tumbuhnya rambut kepala yang dapatterjadi pada wanita maupun pria. Pentingnya peran rambut secara sosial dan estetika mendorong berkembangnya industri obat dan kosmetik untuk rambut(Gilhar, Etzioni, \& Paus, 2012).Alopecia diderita 6,8 juta orang di Amerika Serikat dan 147 juta di seluruh dunia telah atau akan menderita alopecia areata pada titik tertentu dalam kehidupan mereka (Zafrir, Baum, Greenberger, Lyakhovitsky, \& Barzilai, 2016)

Ekstrak dari akar Ginseng (Panax ginseng) adalah bahan dasar dari beberapa sampo dan kondisioner rambut. $70 \%$ ekstrak metanol dari bahan baku yang disebut "ginseng putih" dan "ginseng merah" dan saponin yang diisolasi dan dipelajari dengan pertimbangan khusus tentang pengaruhnya terhadap pertumbuhan rambut dalam kultur in vitro sel-sel folikel rambut pada tikus. "ginseng putih" adalah akar yang mengalami aksi sulfur dioksida dan dijemur atau dikeringkan pada suhu 100-200 ${ }^{\circ} \mathrm{C}$, sedangkan "ginseng merah" diperoleh setelah sterilisasi dengan uap air pada suhu 120-130 ${ }^{\circ}$ C selama 2-3 jam(Dawid-Pać, Urbańska, Dębosz, \& Nowak, 2014). Telah diamati bahwa ekstrak dari akar "ginseng merah" meningkatkan pertumbuhan rambut, tergantung pada dosis, setelah 48 jam dan 72 jam pembiakan. Dosis $50 \mathrm{~g} / \mathrm{ml}$ memiliki pengaruh terbesar. Tindakan ekstrak akar ginseng putih secara signifikan lebih lemah. Hasil-hasil tersebut menunjukkan bahwa sejumlah besar ginsenosida hadir dalam ginseng merah memainkan peran penting dalam

merangsang pertumbuhan rambut

\section{METODE}

Penelitian ini merupakan studi literature review, di mana peneliti mencari, menggabungkan inti sari serta menganalisis fakta dari beberapa sumber ilmiah yang akurat dan valid, yang mendukung dan menjadi bukti. Studi literatur menyajikan ulang materi yang diterbitkan sebelumnya, dan melaporkan fakta atau analisis baru. Tinjauan literatur memberikan ringkasan berupa publikasi terbaik dan paling relevan. kemudian membandingkan hasil yang disajikan dalam makalah.

\section{HASIL}

Etiologi alopecia tidak sepenuhnya jelas namun banyak faktor yang dilaporkan salah satu alasan terkuat terkait dengan gangguan autoimun. Prevalensi tinggi dari perubahan suasana hati, depresi dan gangguan kecemasan biasanya terlihat pada pasien dengan Alopecia. Namun, morbiditas psikiatrik dapat menjadi penyebab dan efek Alopecia (Ito, 2013).

Beberapa jenis alopecia beserta penyebabnya, yaitu Alopecia areata berupa patch rambut rontok yang dapat mempengaruhi setiap bagian tubuh termasuk kulit kepala, wajah, dan ekstremitas. Ketika hanya mempengaruhi sebagian dari area ditubuh, disebut alopecia areata. Ketika mempengaruhi seluruh bagian tubuh disebut alopecia totalis. Ketika melibatkan seluruh tubuh, disebut alopecia universalis. Etiologinya tidak diketahui, tetapi mungkin berhubungan dengan penyakit autoimun (Alkhalifah, 2013).

Androgenetic alopecia adalah pola kerontokan rambut yang dipengaruhi oleh gen dan hormon (androgenik) (Lolli et al., 2017). Telogen effluvium merupakan hasil dari pergeseran fase pertumbuhan siklus rambut (anagen) menuju fase pelepasan (telogen). Keadaan ini merupakan hasil dari penyakit seperti hipo atau hipertiroidisme (Gordon, Gordon, \& Tosti, 
2011). Juga, itu bisa timbul dari stres seperti operasi besar, selain itu, diet ketat, pemberian makan yang buruk, dan obatobatan dapat menyebabkan telogen effluvium (Malkud, 2015).

Alopecia traumatis adalah kerontokan rambut yang disebabkan oleh cedera pada kulit kepala. Di Amerika Serikat, alopesia traumatis adalah bentuk kerontokan rambut yang umum terjadi pada wanita Afrika-Amerika (Bouhanna, 2015). Trikotilomania adalah jenis alopesia traumatis di mana pasien menarik rambutnya berulang kali (Rothbart et al., 2013). Alopecia yang disebabkan oleh Tinea capitis pada disebabkan oleh agen penyebab yang sama dengan tinea capitis.
Anagen effluvium terlihat pada pasien kanker yang menerima agen kemoterapi.

Penjelasan yang masuk akal tentang mekanisme patogen yang dipicu oleh stres emosional dapat dikaitkan dengan produksi mediator neuro, yang mengganggu imunitas. Neuron sensorik ini melepaskan CGRP (37 acid asam amino neuropeptida), dalam ganglion akar dorsal (DRG) dan memiliki aktivitas vasodilatasi yang berpotensi menyebabkan hiperemia jaringan. Isoflavon (phytoestrogen), dan estrogen (hormon seks) meningkatkan produksi CGRP di neuron sensorik dengan meningkatkan transkripsi yang menunjukkan bahwa pemberian isoflavon dapat meningkatkan produksi faktor pertumbuhan Insulin (IGF I), sehingga meningkatkan pertumbuhan rambut.

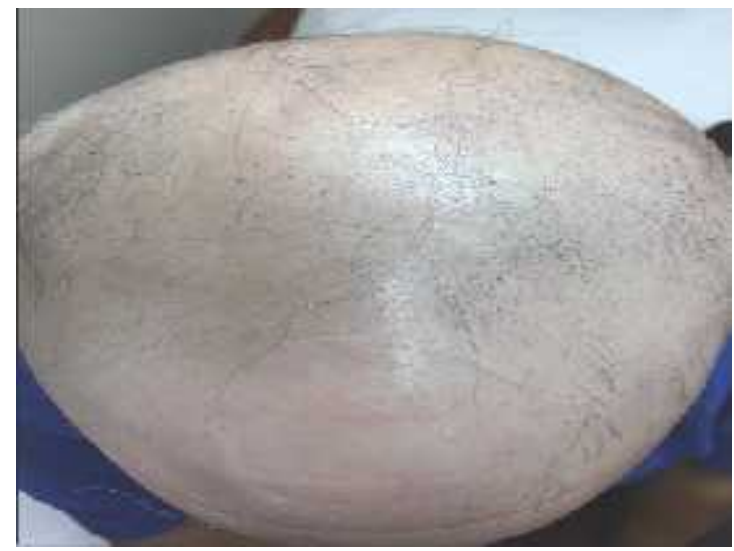

Gambar 1. Alopecia totalis(Darwin et al., 2018)

PEMBAHASAN

Ginseng adalah obat herbal populer yang digunakan di seluruh dunia untuk berbagai indikasi, termasuk diabetes (Yuan, Kim, Kim, \& Chung, 2012), penyakit kardiovaskular (Murthy et al., 2014), penyakit hati kronis (Huu Tung, Uto, Morinaga, Kim, \& Shoyama, 2012), dan dermatitis atopic (Samukawa et al., 2012). Banyak penelitian menunjukan bahwa ginseng memiliki potensi sebagai modalitas terapi untuk pengobatan pada banyak penyakit kulit. Banyak penelitian menunjukkan bahwa Ginseng dapat membantu dalam pengobatan alopesia androgenik. Efek-efek pemacu pertumbuhan rambut ini dikaitkan dengan komponen-komponen ginseng seperti ginsenoside-Rb1 dan 20 (S) -ginsenosideRg3. Ginsenosides adalah komponen utama KRG, dan efek anti-alergi dan antiinflmatorinya telah diidentifikasi. Efek anti-inflamasi ini mungkin terkait dengan kemampuan untuk mempromosikan pertumbuhan kembali rambut. 


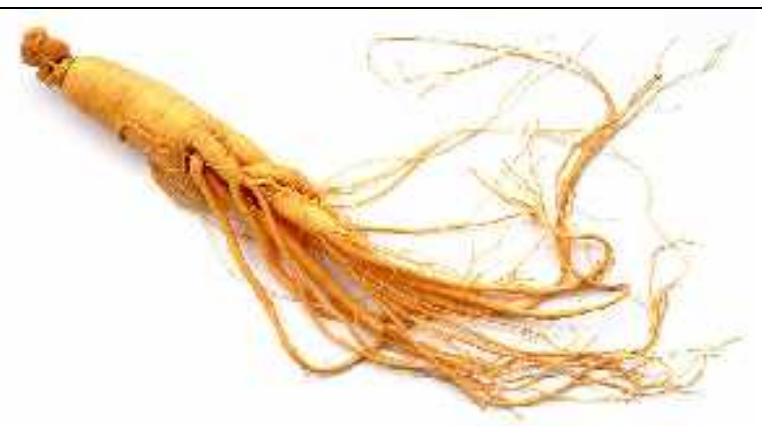

Gambar 2. Panax ginseng

Ada banyak bukti yang menunjukkan bahwa ginseng dan konstituen bioaktif utamanya, ginsenosides, meningkatkan pertumbuhan rambut dengan meningkatkan proliferasi papilla dermal dan mencegah kerontokan rambut melalui modulasi berbagai jalur pensinyalan sel(Keum, Pi, Hwang, \& Lee, 2016). Sementara peran enzim 5a-reduktase dalam proses kerontokan rambut telah didokumentasikan dengan baik (Traish, 2017), mekanisme biokimia yang berkembang dari proliferasi folikel rambut dan proses kerontokan rambut dapat menunjukanperancang terapi baru untuk pengelolaan rambut rontok dan alopecia. Target-target ini termasuk, tetapi tidak terbatas pada, homolog WNT / Dickkopf 1 (DKK1), sonic hedgehog (Shh), faktor pertumbuhan endotel vaskular (VEGF), transforming growth factor-beta (TGF- $\beta$ ), matrix metalloproteinases (MMPs), protein kinase yang diatur oleh sinyal ekstraseluler (ERK), dan kinase teraktivasi Janus (JAK). Bagan berikut merangkum peran ginseng dan metabolitnya pada pertumbuhan rambut:

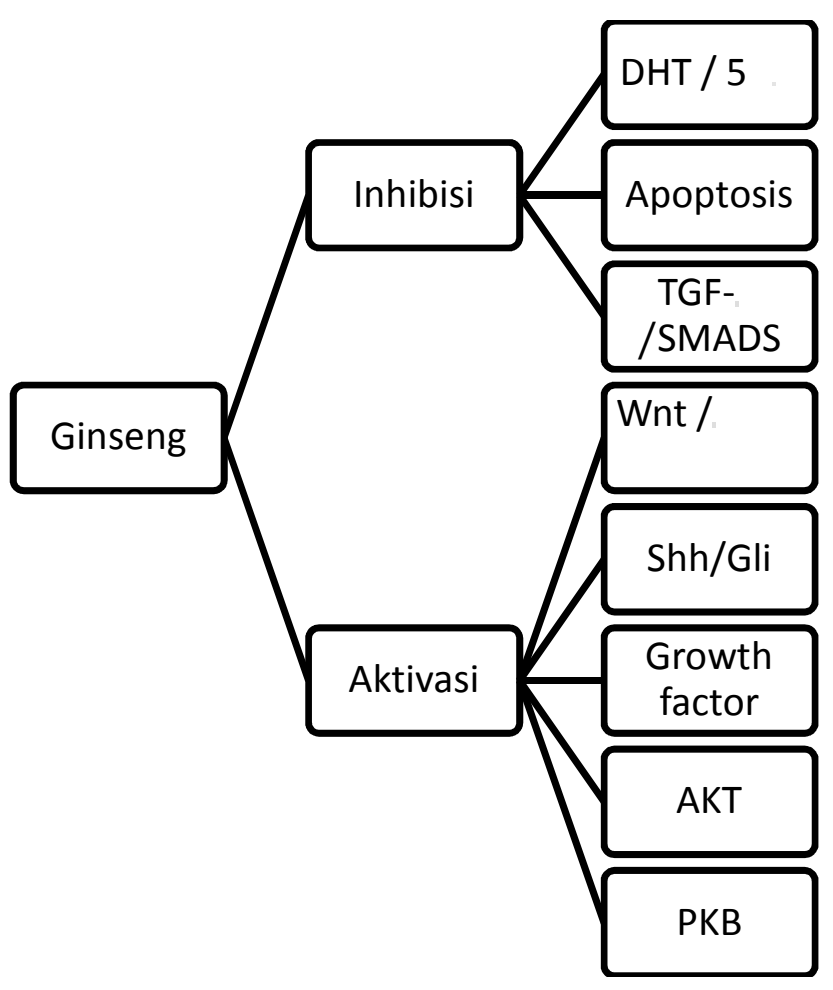

Dalam penelitian yang dilakukan Lee et al efek ekstrak ginseng pada proliferasi sel, efek anti-apoptosis, dan pertumbuhan rambut diamati menggunakan keratinosit cultured outer root sheath dan folikel rambut manusia dengan atau tanpa pengobatan DKK-1. Ekstrak ginseng secara signifikan merangsang proliferasi dan menghambat apoptosis, masingmasing, dalam keratinosit. Pengobatan 
ekstrak PG mempengaruhi ekspresi gen terkait apoptosis Bcl-2 dan Bax. DKK-1 menghambat pertumbuhan rambut, dan ekstrak ginseng secara dramatis membalikkan efek DKK-1 pada kultur organ rambut manusia ex vivo. Ekstrak ginseng menekan perubahan yang disebabkan catagen seperti DKK-1, sebagian, melalui regulasi ekspresi gen terkait apoptosis pada folikel rambut. Temuan ini menunjukkan bahwa ekstrak ginseng dapat mengurangi kerontokan rambut meskipun ada DKK-1, penginduksi katagen yang kuat melalui apoptosis (Lee, Kim, Hong, Park, \& Na, 2017).

Penelitian yang dilakukan oleh Park et al bertujuan untuk menyelidiki efek pertumbuhan rambut dari ekstrak ginseng merah dan ginsenosidesnya. Aktivitas proliferatif folikel rambut manusia berbudaya yang diobati dengan ginseng merah dan ginsenoside-Rb1 dinilai menggunakan immunostaining Ki-67. Efeknya pada sel-sel papilla kulit manusia yang terisolasi (hDPC) dievaluasi menggunakan uji sitotoksisitas, analisis imunoblot protein pensinyalan, dan penentuan faktor pertumbuhan yang terkait. Kemampuan ginseng dan ginsenosides untuk melindungi proliferasi keratinosit matriks rambut terhadap inhibisi yang disebabkan oleh dihidrotestosteron (DHT) dan pengaruhnya terhadap ekspresi reseptor androgen. Efek pertumbuhan rambut in vivo dari ginseng juga diselidiki pada tikus. Baik ginseng dan ginsenoside-Rb1 meningkatkan proliferasi keratinosit matriks rambut. Hasil ini menunjukkan bahwa ginseng merah dapat meningkatkan pertumbuhan rambut pada manusia (Park et al., 2015).

Siklus pertumbuhan rambut terdiri dari tiga fase berbeda, fase anagen, catagen, dan telogen dari folikel rambut independen. Rambut terus tumbuh selama fase anagen, diikuti oleh periode transisi fase catagen, yang masuk ke fase telogen, ketika rambut dilepaskan dari folikel dan jatuh. Fase anagen dapat diklasifikasikan ke dalam fase anagen yang menyebar yang melibatkan aktivasi folikel rambut baru, dan fase anagen otonom, ketika pertumbuhan rambut dan diferensiasi folikel rambut aktif terjadi. Siklus pertumbuhan rambut normal, dapat dimodifikasi atau dipersingkat oleh faktor internal atau eksternal seperti hormon, stres, penyakit tertentu, paparan polusi lingkungan, dan merokok. Perubahan dalam siklus pertumbuhan yang mengarah ke kerontokan rambut dapat direpresentasikan dengan pemendekan fase anagen, penekanan dini fase catagen, dan perpanjangan fase telogen. Kerontokan rambut dini secara medis disebut sebagai alopecia

Ginseng dikeutahui memiliki efek terhadap aktivasi pertumubuhan folikel rambut, namun penelitian lebih lanjut pada manusia harus dilakukan untuk menentukan kadar dan dosis yang tepat digunakan agar menghsilkan efek terbaik terhadap pertumbuhan rambut. Panax ginsengjuga menghasilkan efek pencegahan terhadap kerontokan rambut

\section{SIMPULAN}

Penggunaan produk tanaman dalam terapi telah lama dipraktikkan dan tumumnya aman. Ginseng adalah obat alami multiguna dengan sejarah Panjang dengan aplikasi medis di seluruh dunia, terutama di negara-negara Timur. Penggunaan ginseng secara medis tidak hanya terbatas pada peningkatan kesehatan umum, tetapi juga diperluas untuk pengobatan kondisi patologis spesifik terhadap organ. Di bidang dermatologi, ginseng dan ginsenosida telah terbukti mengatur ekspresi dan aktivitas protein utama yang terlibat dalam fase siklus rambut. Pertumbuhan rambut dan pencegahan kerontokan rambut oleh ginseng dan metabolitnya dikaitkan dengan induksi anagen dan penundaan fase catagen. Meskipun mekanisme yang mendasari di mana ginseng dan metabolitnya mengatur siklus rambut telah dieksplorasi sampai batas tertentu, penelitian lebih lanjut, terutama yang berfokus pada uji coba terhadap manusia, diperlukan untuk pengembangan pengobatan alami terutama 
terhadap kerontokan rambut. Alopecia, yang berasal dari berbagai penyebab, termasuk hiperaktivasi sinyal androgenik, paparan kemoterapi, penuaan, atau fotodamage kulit, dianggap sebagai patologi kulit dan memiliki dampak psikososial yang besar.

\section{DAFTAR PUSTAKA}

Alkhalifah, A. (2013). Alopecia Areata Update. Dermatologic Clinics. https://doi.org/10.1016/j.det.2012.08. 010

Bouhanna, P. (2015). Traumatic alopecia. In The Alopecias: Diagnosis and Treatments. https://doi.org/10.1201/b19440

Darwin, E., Hirt, P., Fertig, R., Doliner, B., Delcanto, G., \& Jimenez, J. (2018). Alopecia areata: Review of epidemiology, clinical features, pathogenesis, and new treatment options. International Journal of Trichology. https://doi.org/10.4103/ijt.ijt_99_17

Dawid-Pać, R., Urbańska, M., Dębosz, I., \& Nowak, G. (2014). Plants as potential active components in treatment of androgenetic alopecia. Herba Polonica. https://doi.org/10.2478/hepo-20140005

Gilhar, A., Etzioni, A., \& Paus, R. (2012). Alopecia areata. New England Journal of Medicine. https://doi.org/10.1056/NEJMra1103 442

Gordon, K., Gordon, K., \& Tosti, A. (2011). Alopecia: evaluation and treatment. Clinical, Cosmetic and Investigational Dermatology. https://doi.org/10.2147/ccid.s10182

Hirobe, T. (2014). Keratinocytes regulate the function of melanocytes. Dermatologica Sinica. https://doi.org/10.1016/j.dsi.2014.05. 002
Huu Tung, N., Uto, T., Morinaga, O., Kim, Y. H., \& Shoyama, Y. (2012). Pharmacological effects of ginseng on liver functions and diseases: A minireview. Evidence-Based Complementary and Alternative Medicine.

https://doi.org/10.1155/2012/173297

Ito, T. (2013). Recent advances in the pathogenesis of autoimmune hair loss disease alopecia areata. Clinical and Developmental Immunology. https://doi.org/10.1155/2013/348546

Keum, D. I., Pi, L. Q., Hwang, S. T., \& Lee, W. S. (2016). Protective effect of Korean Red Ginseng against chemotherapeutic drug-induced premature catagen development assessed with human hair follicle organ culture model. Journal of Ginseng Research. https://doi.org/10.1016/j.jgr.2015.07. 004

Kimura-Ueki, M., Oda, Y., Oki, J., KomiKuramochi, A., Honda, E., Asada, M., ... Imamura, T. (2012). Hair cycle resting phase is regulated by cyclic epithelial FGF18 signaling. Journal of Investigative Dermatology. https://doi.org/10.1038/jid.2011.490

Lee, Y., Kim, S. N., Hong, Y. D., Park, B. C., \& Na, Y. (2017). Panax ginseng extract antagonizes the effect of DKK.1-induced catagen-like changes of hair follicles. International Journal of Molecular Medicine. https://doi.org/10.3892/ijmm.2017.3 107

Lolli, F., Pallotti, F., Rossi, A., Fortuna, M. C., Caro, G., Lenzi, A., ... Lombardo, F. (2017). Androgenetic alopecia: a review. Endocrine. https://doi.org/10.1007/s12020-0171280-y

Malkud, S. (2015). Telogen effluvium: A review. Journal of Clinical and 


\section{Diagnostic Research. https://doi.org/10.7860/JCDR/2015/1 5219.6492}

Murthy, H. N., Kim, Y. S., Jeong, C. S., Kim, S. J., Zhong, J. J., \& Paek, K. Y. (2014). Production of ginsenosides from adventitious root cultures of panax ginseng. In Production of Biomass and Bioactive Compounds Using Bioreactor Technology. https://doi.org/10.1007/978-94-0179223-3_24

Park, G. H., Park, K. Y., Cho, H. Il, Lee, S. M., Han, J. S., Won, C. H., ... Lee, D. H. (2015). Red ginseng extract promotes the hair growth in cultured human hair follicles. Journal of Medicinal Food. https://doi.org/10.1089/jmf.2013.303 1

Rothbart, R., Amos, T., Siegfried, N., Ipser, J. C., Fineberg, N., Chamberlain, S. R., \& Stein, D. J. (2013). Pharmacotherapy for trichotillomania. Cochrane Database of Systematic Reviews. https://doi.org/10.1002/14651858.C D007662.pub2

Samukawa, K., Izumi, Y., Shiota, M., Nakao, T., Osada-Oka, M., Miura, K., \& Iwao, H. (2012). Red ginseng inhibits scratching behavior associated with atopic dermatitis in experimental animal models. Journal of Pharmacological Sciences. https://doi.org/10.1254/jphs.11182FP

Traish, A. M. (2017). Negative impact of testosterone deficiency and $5 \alpha$ reductase inhibitors therapy on metabolic and sexual function in men. In Advances in Experimental Medicine and Biology. https://doi.org/10.1007/978-3-31970178-3_22

Yuan, H. D., Kim, J. T., Kim, S. H., \& Chung, S. H. (2012). Ginseng and diabetes: The evidences from in vitro, animal and human studies. Journal of Ginseng Research. https://doi.org/10.5142/jgr.2012.36.1 .27

Zafrir, Y., Baum, S., Greenberger, S., Lyakhovitsky, A., \& Barzilai, A. (2016). ALOPECIA AREATA. Harefuah. https://doi.org/10.5694/j.13265377.1952.tb100359.x 
Jurnal Penelitian Perawat Profesional, Volume 2 No 1 Hal 71 - 78, Februari 2020 Global Health Science Group 